Reviews in Digital Humanities • Vol. 3, No. 2

\title{
Review: East Asia For All
}

\section{Paul Vierthaler ${ }^{1}$}

${ }^{1}$ William \& Mary

Published on: Feb 14, 2022

License: Creative Commons Attribution 4.0 International License (CC-BY 4.0). 


\section{Project}

East Asia For All

Project Directors

Stephanie Montgomery, St. Olaf College

Melissa Brzycki, Monmouth University

Project URL

https://www.eastasiaforall.com/

Project Reviewer

Paul Vierthaler, William \& Mary

\section{Project Overview}

\section{Stephanie Montgomery and Melissa Brzycki}

East Asia for All (EAFA) is a public history podcast that explores East Asian popular culture and media through a historical lens. The podcast focuses on East Asian pop cultural products-including movies, TV series, documentaries, fiction, and memesand their relevance to understanding different aspects of East Asian life and culture. Hosts and producers Melissa Brzycki and Stephanie Montgomery are both historians of China with training in East Asia, and they have a decade of experience living and working in China, Taiwan, and Japan. They both received their doctorates in history from the University of California at Santa Cruz in 2018. Montgomery is an Assistant Professor of History and Asian Studies at St. Olaf College and Brzycki is an Assistant Professor of History at Monmouth University.

Episode formats include both long-form episodes (45 min-1 hour), which typically include interviews with outside scholars, and mini-episodes (20 min) featuring discussion by the two podcast hosts. For both forms, the podcast utilizes the humanistic methods of critical evaluation and analysis to examine pop culture products through a historical lens. The project also strives to use accessible language to give mainstream audiences basic historical background and context for beloved pop culture products of East Asia.

Most Americans learn about East Asia through television, movies, and news reports, which generally focus on stereotypes, disasters, and perceived threats to the U.S. In response, we use popular culture as an entry point to accomplish two humanistic 
goals. First, the podcast aims to draw attention to generally unknown or misunderstood historical experiences in East Asia. For example, Episode 8, a long-form interview episode with Kelly Jeong on Park Chan-wook's film The Handmaiden (2016), demonstrates how the horror-romance film can help audiences better understand the Japanese colonial period (1910-1945) on the Korean peninsula. Second, the podcast attempts to combat mainstream stereotypes and whitewashing of East Asian peoples and cultures. Episode 3 featuring Noriko Aso, for example, examines the controversy around the live-action film Ghost in the Shell (2017), in which white actress Scarlett Johansson was cast as protagonist Major Motoko Kusanagi.

EAFA has been funded by grants from the U.S. Department of State's Critical Language Scholarship Alumni Development Fund, the Philips Ambassador Alumni Award at the University of North Carolina at Chapel Hill, and a fellowship from The Humanities Institute at the University of California, Santa Cruz. EAFA episodes have also attracted a sizable audience. To date, there have been 10,000 downloads of the eighteen current episodes, and over 16,000 unique visitors to the podcast website. In part, we attribute this growing following to an interest in history podcasts with high production values that are well-researched and accessible. EAFA seeks to meet these new audience expectations by meeting the American Historical Association's Digital Scholarship Guidelines of "expanding what history is, and can do, as a field." In doing so, the podcast reflects the Modern Language Association's description of digital scholarship as blurring "the traditional boundaries between teaching, research, and service" with content not only for academic colleagues and students, but also in service to the broader community.

\section{Project Review}

\section{Paul Vierthaler}

East Asia for All (EAFA) is a public humanities project run by Melissa Brzycki and Stephanie Montgomery that focuses on popular culture in East Asia. This project consists of a podcast and online supplemental material that provides anyone interested in East Asian culture with easy-to-understand introductions to a wide range of topics in East Asian pop culture. Brzycki and Montgomery deftly cover topics that range from the now-banned-in-China environmental documentary Under the Dome (2015), to the representation of postcolonial Taiwan in the movie Cape No. 7 (2008), to the proliferation of anti-Asian racism in the COVID-era, to fascism in imperial Japan. They enrich their content by bringing in other experts to contribute to the discussion, and 
the podcast truly shines in moments when it reflects on the broad implications a given pop cultural topic has on understanding East Asian culture, history, and politics. The podcast began as a collaborative project between Brzycki and Montgomery when they were graduate students at UC Santa Cruz and has benefited by funding from sources ranging from UC Santa Cruz and UNC Chapel Hill to the American Council for International Education.

The individual episodes all contain fascinating content and offer listeners a gentle introduction to pop culture without essentializing or orientalizing the subject matter. The mini-episode on Tampopo is a case in point. This "ramen western," directed by Juzo Itami and released in 1985, played an important role in the internationalization of ramen culture, despite its satirical nature. As in many episodes, Brzycki and Montgomery first center their discussion at the personal level by describing their first encounters with Tampopo before leveraging this starting point into a wide-ranging conversation that covers cinematic history and the "fetishization of Japanese cultural products." The episode provides context that helps listeners understand not just the movie, but also the history of ramen more broadly. Like all their episodes, it will appeal both to those already familiar with the movie and to those who have never seen it.

One of the most compelling parts of the East Asia for All project is "EAFA in the Classroom," a digital resource that pairs with the podcast to make teaching the materials significantly easier. Funded by the Digital Scholarship Commons at UC Santa Cruz, the website is aimed at both high school and college audiences. They currently have posted resources for at least one lesson: "The Everyday in Wartime: Imperial Japan." The post includes introductory and reference material, discussion questions, lesson objectives and instructions, secondary readings, and even suggestions for how to adapt the lesson for high school students. In addition to this extensively prepared lesson, each episode of the podcast is accompanied by online supplementary material that includes a brief introduction and links to relevant readings and websites.

While East Asia for All covers a diverse array of topics, I would like to see more coverage focused on South Korea. This would be welcome to a broad audience, particularly given the current interest in South Korean cultural exports like K-Pop and television shows. More lessons in "EAFA in the Classroom" would also be great to see, as this is one of the most clearly beneficial components of the project.

The unique combination of podcast and online material Brzycki and Montgomery have produced make this project invaluable for anyone who hopes to bring lessons on East Asian pop culture into their classroom. Its focus on both secondary and higher 
education fills a much-needed educational space and makes it a resource that anyone working on contemporary East Asia should be familiar with. Beyond professionals, however, the podcast format of East Asia for All makes it quite accessible to- and very bingeable by-anyone with even a passing interest in East Asian popular culture. 